\title{
リーフ地形周辺の海上作業可否に着目した 波浪予測モデルの検討
}

\author{
琴浦 毅1・片山 裕之2 \\ 1 正会員 五洋建設（株）技術研究所（一329-2735 栃木県那須塩原市四区町 1534-1） \\ E-mail: Tsuyoshi.Kotoura@mail.penta-ocean.co.jp \\ 2 正会員 五洋建設 (株) 技術研究所（广329-2735 杤木県那須塩原市四区町 1534-1） \\ E-mail: Hiroyuki.Katayama@mail.penta-ocean.co.jp
}

\begin{abstract}
海上工事を安全で効率的に進めるために気海象予測情報の取得は重要な課題であるが, 作業限界波高 1.0 $\mathrm{m}$ 程度の波浪推算精度についての検証例は少ない。また，リーフ周辺は地形や波浪場が複雑であるため, 数值解析においても課題が多い。 そこで, 本研究ではリーフ地形周辺の現地波浪観測を行い, その結果を 用いて，海上作業可否判断に資する波浪予測モデルの構築を試みた。

現地観測の結果，リーフ周辺の波はリーフエッジ沿いに屈折しながら回りこむ波浪が支配的であったた め，浅海域の波浪解析手法としてエネルギー平衡方程式を用いてリーフを回りこむ波を評価し，沖波に対 する対象地点の波高比を算出した。WA で求めた沖波推算波高に，算出した波高比を乗じて予測值を提 供する簡易波浪予測モデルを構築し，そのモデルが実務的な精度を有していることを確認した。
\end{abstract}

Key Words : Wave prediction accuracy, WAM model, marine works, reef

\section{1. はじめに}

海上作業を伴う海洋工事を安全で効率的に行うため に, 国土交通省や工事施工者は気象・海象観測網の整備, 予報情報の取得に努めてきた ${ }^{1)}$ 。また，近年では，計算 機の性能向上や計算手法の高度化などが著しく，観測值 と波浪予測值を同化することで予測精度の向上を図れる 波浪推算システムなども構築されている22. しかし，波 浪推算モデルの推算精度に関しては, 高波浪に着目して 検討されたものが多く, 海上作業の可否判断である波高 $1.0 \mathrm{~m}$ 程度の精度に関する検証例は十分とは言えない(3) 5). またサンゴ礁海域では，水深の浅いリーフフラットを 有することが多く，さらに，そのリーフ前面の海底勾配 は急傾斜勾配となっているなど, 地形的に複雑である. サンゴ礁海域での波浪変形を捉える試みは以前よりなさ れており，津嘉山らは現地観測結果を用いて高山らのリ 一フ上の波高の実験式を修正しているの,7). また，平山ら はリーフ周辺の波浪変形計算にブシネスク方程式を適用 し，設計波レベルにおけるリーフ内部の護岸越波量を評 価している ${ }^{8)}$,9).また, 高山らはサンゴ礁海域を対象に, 施工時の濁り拡散モデルを構築しているが，現地観測と の比較までは至っていない ${ }^{10)}$.

本研究では，リーフ地形周辺における波浪特性を現地 観測結果から検証し，その結果からWAMを基本とした
予測モデルを構築することで, リーフ地形周辺の海上作 業可否に着目した実務的な波浪予測モデルを確立するこ とを目的とした.

\section{2. 現地観測}

\section{(1) 現地観測の条件}

対象とした海域は図-1に示す沖縄県那覇地区である. 通常，波による施工可否判断を必要とする海上工事は船 舶を用いて施工することが多いため，作業船の喫水を考 慮するとある程度の水深（概小 $25 \mathrm{~m}$ 程度）以上が施工範 囲となることが多い. 従って，作業船舶の喫水より浅い リーフフラット（図-1の紫色の範囲）上は今回の研究観 測対象とせず, リーフフラット周辺の波浪場に着目して, 表-1，図-1に示すリーフ北側に波高計を2台（St.1，St.2） 設置した.リーフエッジからの距離はSt.1 : $30 \mathrm{~m}$, St.2 : $300 \mathrm{~m}$ 程度となっている. また, St.2の近傍には設置水 深より浅い水深 $15 \mathrm{~m}$ 程度の島瀬が存在している. 観測期 間は2014年8月15日〜2014年10月26日であり，0.5 sの連続 観測データを取得した.

\section{(2)＼cjkstart現地観測の結果}

現地観測の結果をNOWPHAS那覇 (2014年: 速報值) 
表-1 観測諸元

\begin{tabular}{|c|c|c|c|}
\hline 地点名 & 水深(m) & 対象期間 & 観測モ一ド \\
\hline NOWPHAS那覇 & 51 & \multirow{3}{*}{$\begin{array}{l}\text { 2014年8月 } 15 \text { 日 } \\
\text { 2014年10月26日 }\end{array}$} & \multirow{3}{*}{$\begin{array}{c}20 \text { 分連続観測 } \\
\text { サンプリング間隔: } 0.5 \mathrm{~s} \\
\text { 観測成分: } 4 \text { 成分 } \\
\text { (水位, 水圧, 流速 }(\mathrm{U}, \mathrm{V})\end{array}$} \\
\hline St. 1 & 15 & & \\
\hline St.2 & 22 & & \\
\hline
\end{tabular}
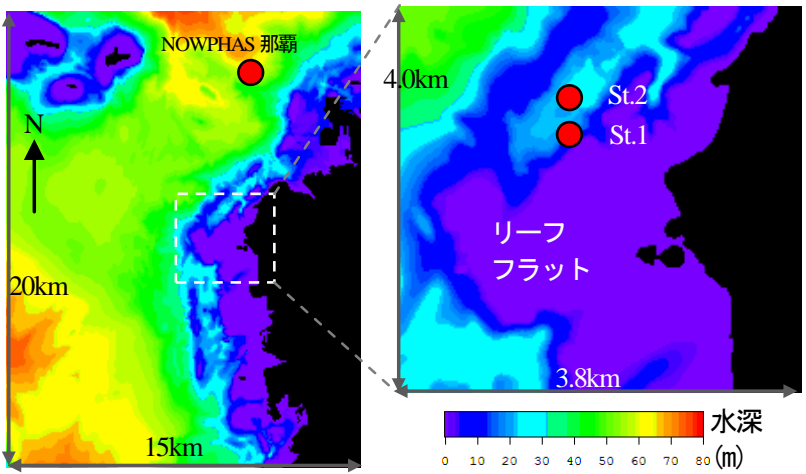

図-1 リーフ地形と波高計位置

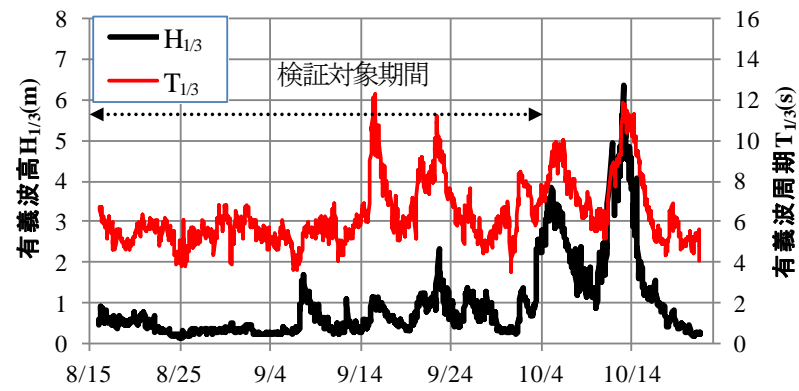

図-2 NOWPHAS 那覇観測時系列

のデータと合わせて検証する．図-2に観測期間中の NOWPHAS那覇の時系列を示す. 10月4日以降は台風18 号，台風19号による顕著な高波浪が観測されているが， 本研究の目的は海上作業可否判断の波高 $1.0 \mathrm{~m}$ 付近を対 象としているため，明らかに作業不可となるこの期間を 除外して検証対象期間とした.

図-3 に検証対象期間における NOWPHAS 那覇と設置 した 2 台の波高計の有義波高, 波向の時系列を示寸。こ の観測結果を見ると, NOWPHAS 那覇, St.2 では作業限 界波高 $1.0 \mathrm{~m}$ を上回る高波浪(1) (4)が 4 回観測されてい るのに対し，St.1では高波浪(2)で波高 $1 \mathrm{~m}$ を下回り，高 波浪(3)では他地点と比較して波高が大幅に小さく波高 1 $\mathrm{m}$ 程度となっている. この時の NOWPHAS 那覇の波向 はSW となっていることから，南側からの来襲波である ことが予想される. そのため, St.1 においては南側リー フによる遮蔽を受けるため波高が低減するものの, St.2 においては遮蔽による影響が比較的小さいため, 結果と して波高の低減も小さいと考えられる.

この遮蔽域の影響を定性的に評価するため, 図-4に NOWPHAS 那覇の波向 N, SW における, NOWPHAS 那覇と St.1，St.2 の波高の相関を示した. NOWPHAS 那 覇と St.1, St.2 の波高が一致すればその勾配 (回帰係数) は 1.0 となる. 波向 N は St.1, St.2 の回帰係数 0.9 程度と
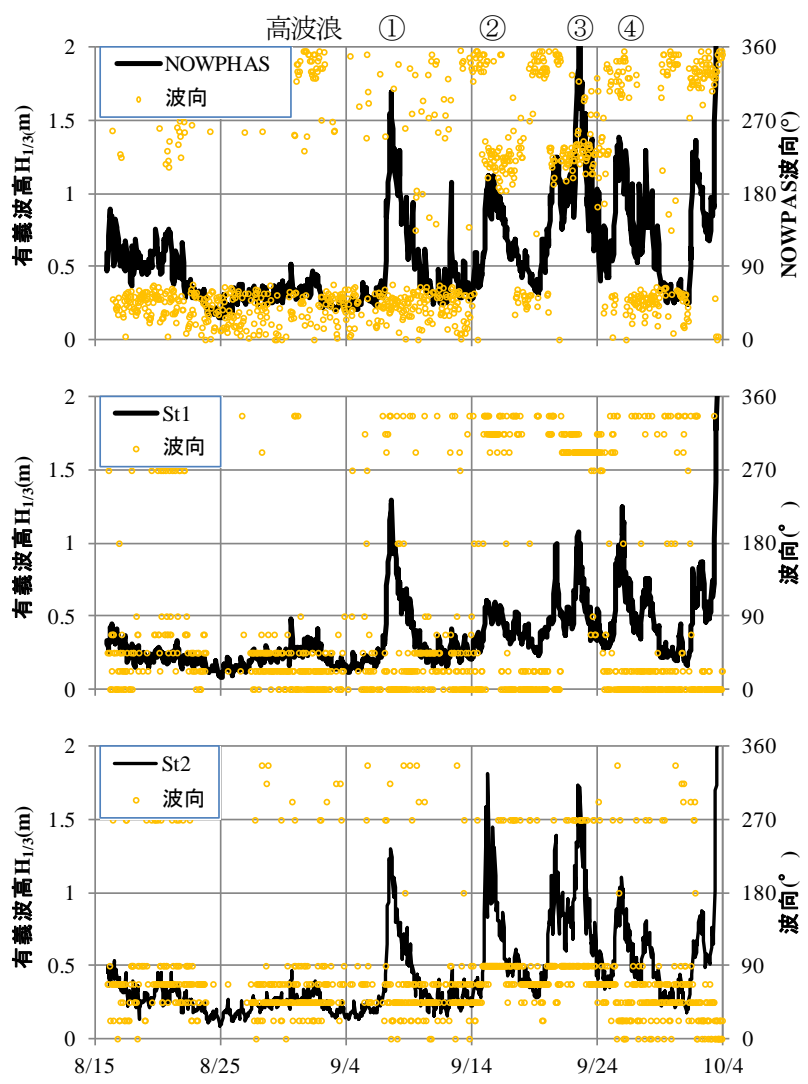

図-3 波高計時系列比較
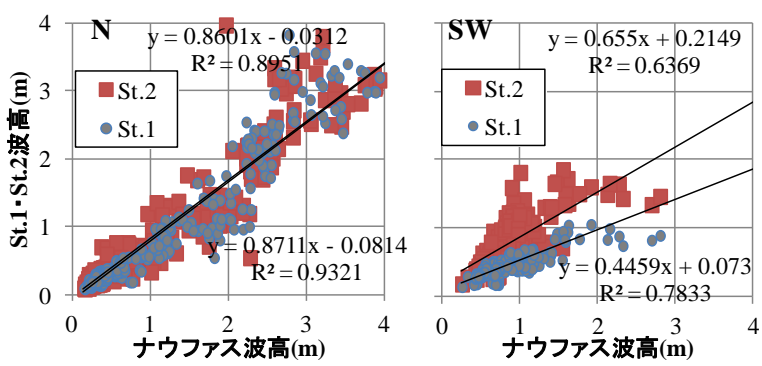

図-4 NOWPHAS 那覇に対する波高比

なり, NOWPHAS 那覇とほぼ同程度の波が来襲している と考えられる. しかし，SW では St.2 の回帰係数 0.66 に 対して, St.1 の回帰係数は 0.45 と 0.2 程度低下しており, NOWPHAS 那覇と比較すると低い波高となっている. 図-4において, 波向 SW の St.2 の相関係数はその他のケ 一スと比べると低くなっている．例えば，高波浪(2)の時 には NOWPAS 那覇の波高が $1 \mathrm{~m}$ 程度なのに対し, St.2 では $2 \mathrm{~m}$ 近い波高となっている. NOWPHAS 那覇と比較 すると南側リーフの遮蔽に近いにも関わらず，St.2 の波 高の方が大きくなるのは，設置位置近傍の島瀬の影響に よる波の集中が起こっているものと考えられる.

図-5 に各波向の St.1, St.2 の波高比を示した. NOWPHAS 那覇の観測波向は速報值であり, 20 分毎に 波向が頻繁に変化している時間帯があるなど不確実性は あるものの，西〜南方向の波向時に St.1，St.2 の差が顕 




図-5 波向別波高比

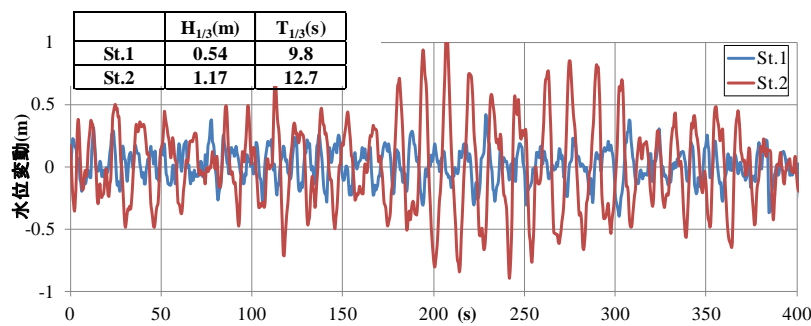

図-6 観測水位時系列の比較

(2014 年 9 月 15 日 12 時)

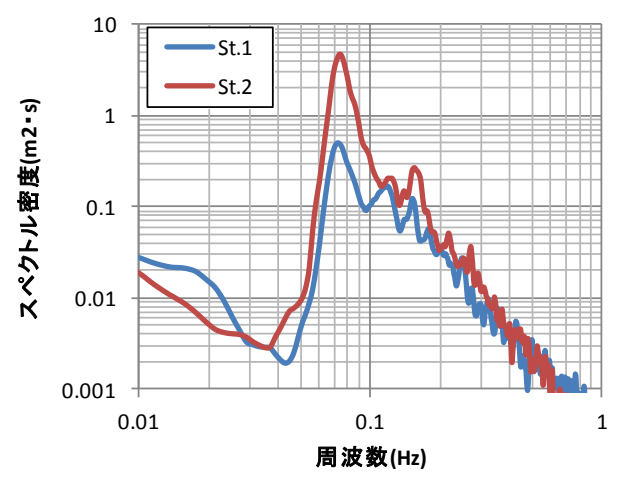

図-7 周波数スペクトルの比較

(2014年 9 月 15 日 12 時)

著になっている．これは，波高計設置位置の南側リーフ による遮蔽が波向によって異なるためと考えられる.

なお，この観測期間中においては NOWPHAS 那覇で 波向 S はほとんど観測されておらず，従来の観測結果と 同様の傾向となっている ${ }^{11)}$. しかし，沖波では波向 S は 存在するのは明らかであるため, NOWPHAS 那覇の地点 は南側リーフの遮蔽による影響であると考えられる。つ まり, NOWPHAS 那覇でSSW〜SW となっている波向の 中には，沖波で $\mathrm{S}$ の波向が混在していると推察される.

図-6 は St.1 で NOWPHAS 那覇と比較して波高減衰が 顕著である高波浪(2) 9/15 12:00の St.1，St.2 の観測水 位時系列である. St.2 では波群性を有しているものの, St.1 では波群性がなくなり，水位変動は減少している. ゼロクロス解析から算出される有義波高 $\mathrm{H}_{1 / 3}$ は St.2:1.17 $\mathrm{m}$, St. $1: 0.54 \mathrm{~m}$ と半分程度に低減しており, 有義波周期 $\mathrm{T}_{1 / 3}$ は St. $2: 12.7 \mathrm{~s}$, St. $1: 9.8 \mathrm{~s}$ と 3 秒程度短周期となって いる．図-7 は St.1，St.2 の周波数スペクトルであるが,
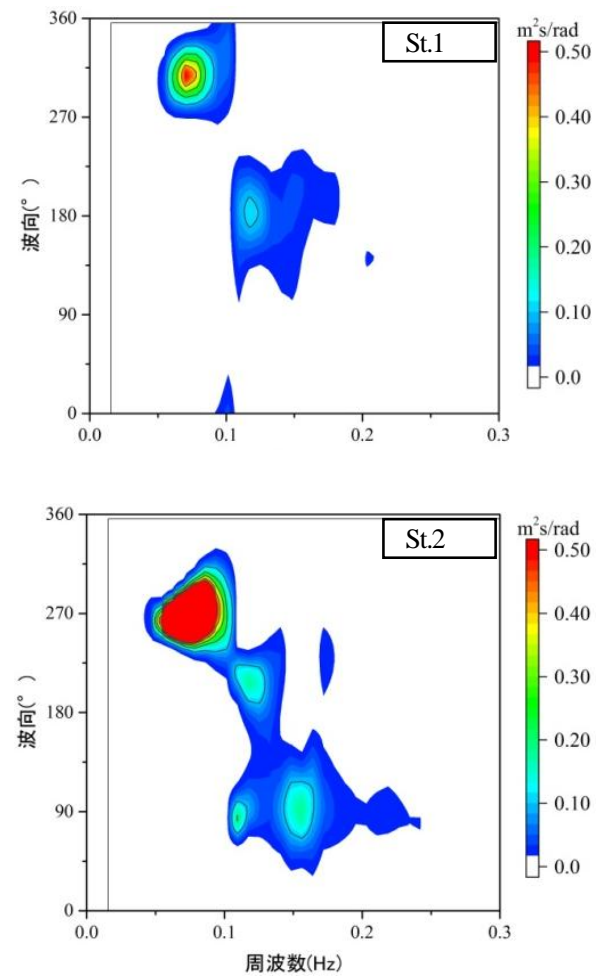

図-8＼cjkstart方向スペクトルの比較

(2014 年 9 月 15 日 12 時)

St.1 ではピーク周波数である $0.07 \mathrm{~Hz}$ 付近のエネルギー が減少していることが，波高，周期低下の要因であると 考えられる。

図-8 は St.1，St.2 の方向スペクトルである.ピーク周 波数付近に着目すると, St.2ではW 方向であるのに対し, St.1ではリーフ直交方向の NW 方向が卓越している.こ の時の沖波向は後述する WAM の結果を用いると S と推 定される. しかし，St.2 は南側リーフ遮蔽による波浪変 形により S の波向が W 方向となり, St.1 はさらにリーフ 方向一屈折により波向が変化していると考えられる.ま た，St.1 では屈折に加え急勾配リーフによる砕波エネル ギー逸散が発生していると推察される。

なお，方向スペクトルを確認すると，いずれの地点も ピーク周波数の倍周波数付近に S 方向のエネルギーが存 在している．波向を考慮すると，沖向き $\mathrm{S}$ の波がリーフ フラットを伝播，通過した波であると考えられる。つま り，いずれの地点においてもリーフを回り込む波と，リ 一フフラット上の伝播波が合成されている 2 方向性の波 浪場になっていることが確認された。ここで，リーフフ ラット上の伝播波の $\mathrm{H}_{\mathrm{m} 0}$ は $0.33 \mathrm{~m}$ 程度であり, St.1, St.2 のいずれにおいても大きな差はない，仮にこのエネルギ 一を考慮せずに算出した St.1，St.2 の $\mathrm{H}_{\mathrm{m} 0}$ は $0.43 \mathrm{~m}, 1.13$ $\mathrm{m}$ であり，観測值 $(0.54 \mathrm{~m}, 1.17 \mathrm{~m})$ と比較して大幅に波高 が低減されるものではない，したがって，当該地点にお いてはリーフを回り込む波を評価できれば実務上の予測 精度は有すると考えられる。 
表-2 WAM モデルのパラメータの設定

\begin{tabular}{|c|c|c|}
\hline 領域 & XL & LL \\
\hline 計算領域 (北緯) & $-70^{\circ} \sim 60^{\circ}$ & $20^{\circ} \sim 50^{\circ}$ \\
\hline 計算領域 (東経) & $117^{\circ} \sim 295^{\circ}$ & $120^{\circ} \sim 150^{\circ}$ \\
\hline 最小周波数 & \multicolumn{2}{|c|}{$0.042 \mathrm{~Hz}$} \\
\hline 周波数分割数 & \multicolumn{2}{|c|}{35} \\
\hline 方向分割数 & \multicolumn{2}{|c|}{16} \\
\hline 水深条件 & \multicolumn{2}{|c|}{ 深海 } \\
\hline 空間閒隔 & $0.5^{\circ}$ & $0.1^{\circ}$ \\
\hline 伝播計算時間刻み & $900 \mathrm{~s}$ & $300 \mathrm{~s}$ \\
\hline 風データ時間間隔 & \multicolumn{2}{|c}{$3600 \mathrm{~s}$} \\
\hline
\end{tabular}

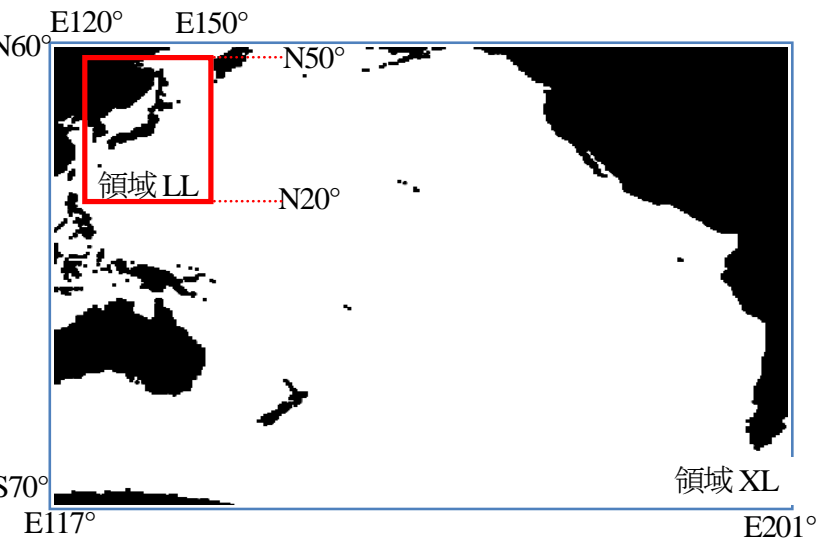

図-9 XL，LL 計算領域図

\section{3. 数値解析}

\section{（1） 波浪予測モデル}

波浪推算モデルとしてはWAM モデルを用い，モデル のパラメータを表-2，解析領域を図-9 に示した．解析領 域は既往の検討による計算条件に等しく, 太平洋領域XL を計算し，日本近海の計算領域 LL に接続するネステ イングを行った. 入力風は気象庁 GPV のうち GSMgl, GSMjp を用い，6 時間先までの計算を実施し，それを初 期值として随時計算を行った.

WAM は深海モデルであるため海底地形の影響を考慮 できず，また，日本近海の計算領域 LL の格子サイズは $10 \mathrm{~km}$ 程度であるため地形の詳細な考慮ができない. そ こで, WAM の結果を入力とする浅海域の波浪変形モデ ルを別途検討することとした.

現地観測結果から，リーフフラット上の伝播波の存在 は確認したものの，リーフ周辺の波浪場を実務的に予測 するには，リーフ上の波高を再現できるモデルは必要な く, リーフエッジに沿って屈折しながら回り込む波を再 現可能な簡易なモデルでよいと考えられる. 本研究では,

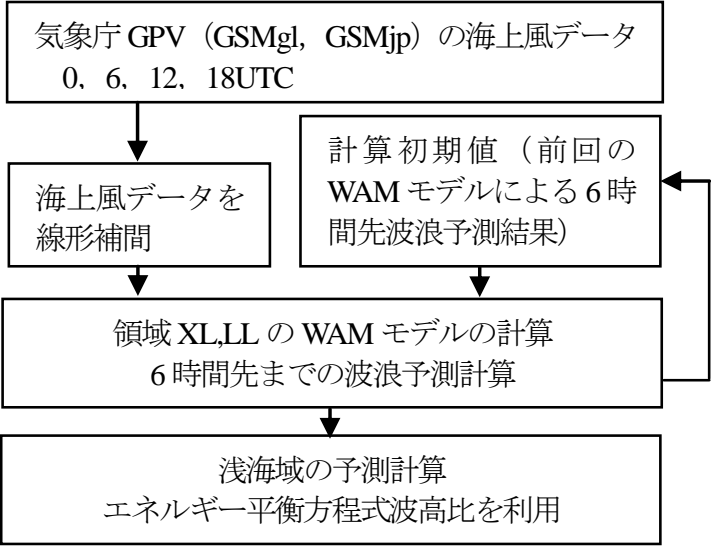

図-10 データ入力から予測までのフロー

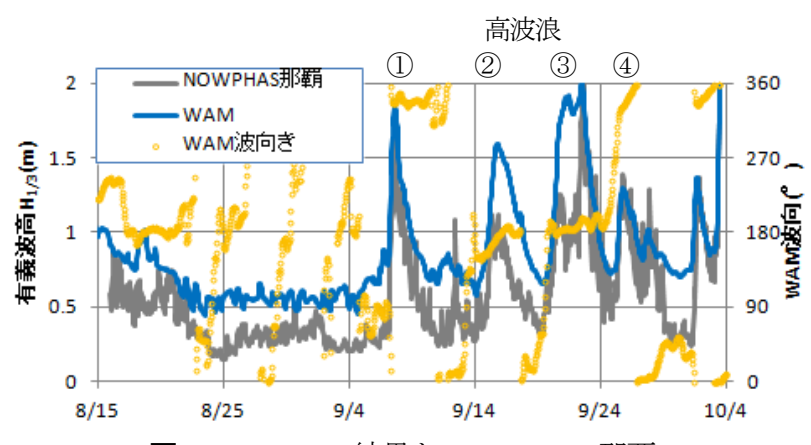

図-11 WAM の結果と NOWPHAS 那覇

リーフ周辺の伝播波を評価するモデルとして，エネルギ 一平衡方程式を用いることとした. エネルギー平衡方程 式を沖波向の周期，潮位を変化させた計算を実施して得 られた沖波に対する対象地点の波高比をデータベース化 し, WAM で得られた沖波条件（波向，周期）に応じて 波高比を乗じることで対象地点の波高予測值を得ること とした（図-10）.

\section{（2）波浪予測モデルの精度}

WAM の推算值と NOWPHAS 那覇の観測值の比較を図 -11 に示す. 地形の影響を受けにくい WAM の波向が北 寄りの条件では推算值と実測值が比較的良く対応してい る. その一方で，南寄りの波向時には，地形による影響 により観測值は推算值より波高が低減しており，WAM の結果をそのまま用いるのが難しいことが確認された.

そこで, NOWPHAS 那覇を含む浅海域の推算值は以下 の手順で算出した，当該地区近傍のWAM 計算格子にお ける波高, 波向, 周期を抽出し, 波向, 周期に応じてエ ネルギー平衡方程式で算出した波高比を選定し，WAM 波高にその波高比を乗じることで浅海域の推算值に変換 した. 図-12 はその推算值と観測值との比較である.

NOWPHAS 那覇においては潮位による推算值の差はほ とんど見られない，これは，対象位置がリーフから離れ た位置にあるため，リーフによる遮蔽，屈折などの影響 が潮位の変化に対して有意でないためと考えられる。ま 

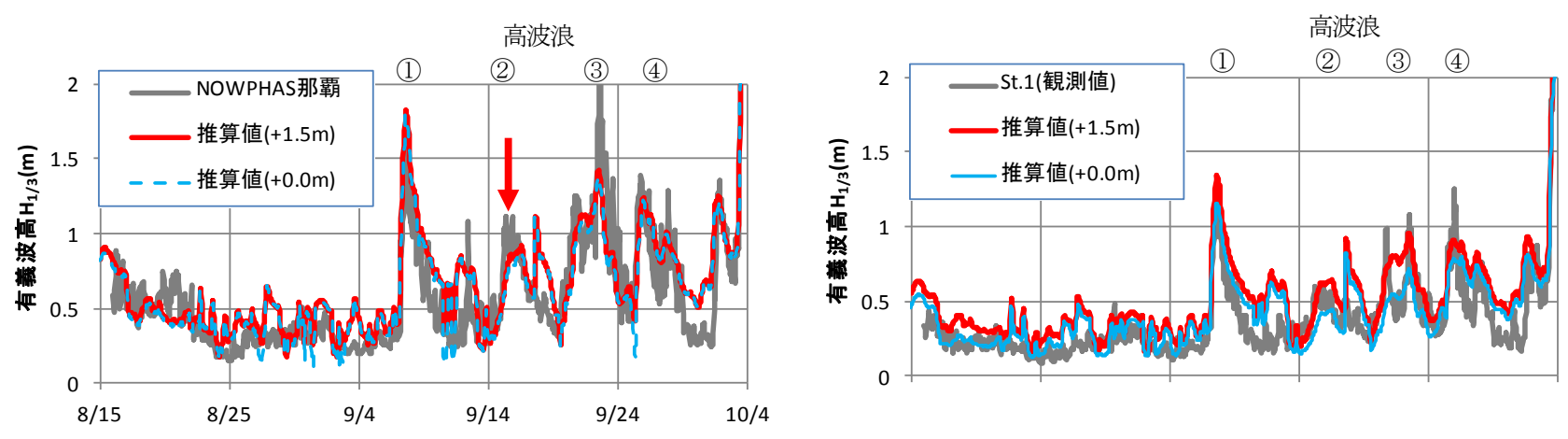

図-12 実測值と予測值の比較（NOWPHAS 那覇）
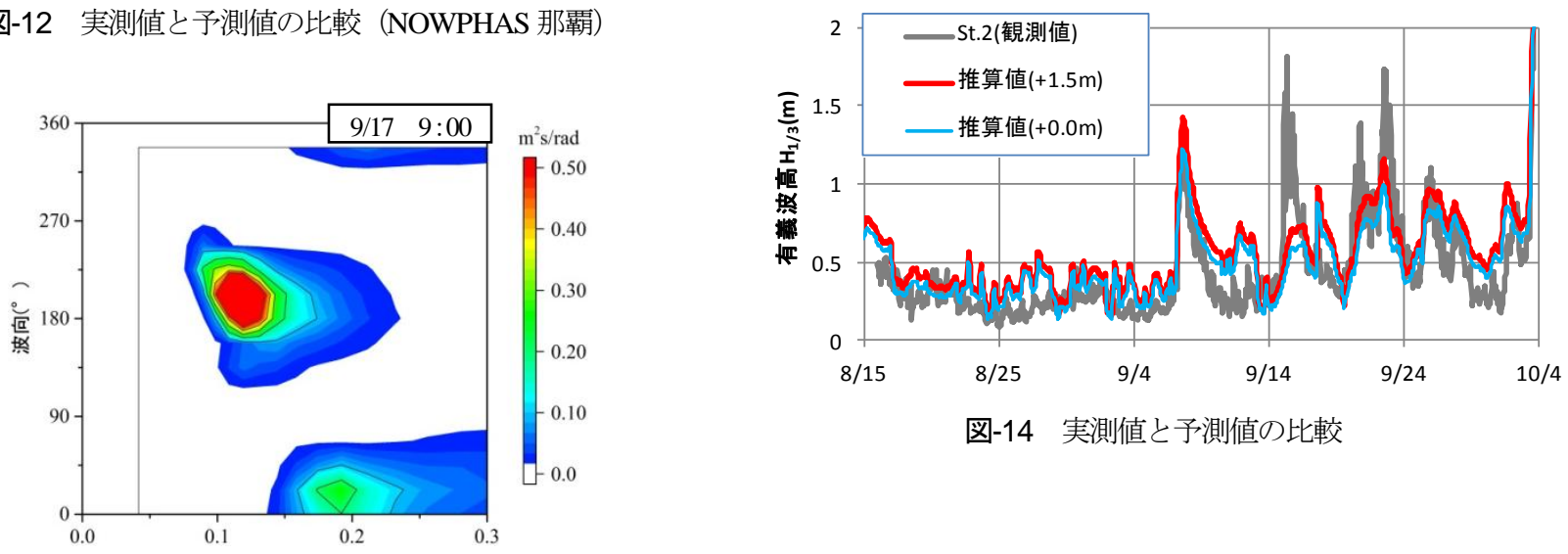

図-14 実測值と予測值の比較

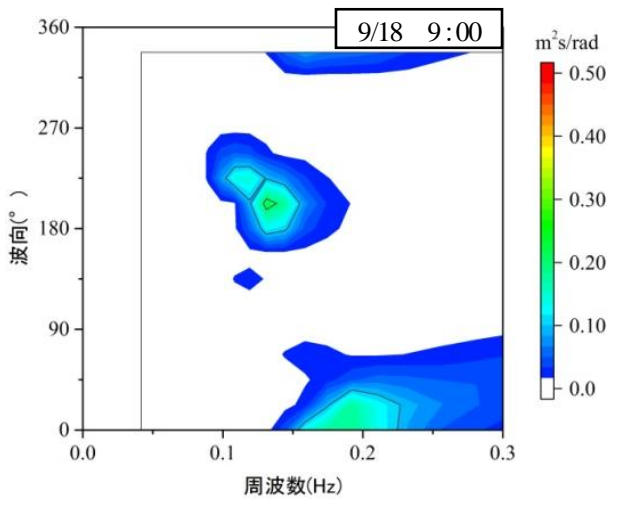

図-13ＷAM の方向スペクトルの変化

た，高波浪(3についてはピーク時の再現性が良くないも のの, $1.0 \mathrm{~m}$ を上回る予測をしている点で作業可否判断 としては有用な情報と考えられる.

しかし，高波浪(2)の後半の推算值に，観測值には無い ピークが存在している (図中の赤矢印位置). 図-11の WAM 波向を確認すると，南寄りの波が短時間で北寄り に変化している．この時間では北風により北寄りの波が 発生していると考えられる. その一方で, 高波浪後のう ねりが南側から来襲している 2 方向性の波浪場になって いることが，図-13 の方向スペクトルから確認できる.

また，図-13の 2 枚の図面から，時間経過とともに南 寄りのう㸚りエネルギーが減少し，北寄りの波浪成分が 主体的になることが確認されるが，2 方向性は維持され ている. しかし，WAM で算出した沖波推算值の波向， 周期に応じてエネルギー平衡方程式の波高比を乗じて予

測值を算出する際に，1 方向性の波として波高比が大き い北寄りの波高比を用いたため，推算值が過大評価にな ったと考えられる.この時，それぞれの波向のエネルギ 一に対して，対応する波高比を乗じると精度が向上する ことが確認された．したがって，波向によってリーフの 遮蔽が顕著となる地点において波浪が多方向性を有する 場合，WAM からの変換時にも工夫が必要であることが 分かった.

図-14 は St.1, St.2 の推算值と観測值との比較である. St.1 の推算值は概襍観測值と対応しており，高波浪(2), (3)が波高 1.0 m を下回る結果となっている.つまり, リ 一フの影響が小さいと考えられる NOWPHAS 那覇のみ で判断した場合，波高 $1 \mathrm{~m}$ を上回るため施工ができない 条件であるにも関わらず，リーフの影響を考慮すること で，施工可能であることが評価できたことから，施工可 否判断一の活用が可能なレベルと考えられる. また, NOWPHAS 那覇と比較すると, 南寄りの波浪場において 潮位による波高差が顕著に見られる.9/15 12:00 は満潮位 であったが, 潮位 $+1.5 \mathrm{~m}$ 推算值が潮位 $+0.0 \mathrm{~m}$ 推算值と比 較してよく対応している。これは，急勾配斜面を有する リーフ周辺海域では, 潮位の変化による水深変化が顕著 となることから，屈折への影響が変化するためと考えら れる.

St.2 の推算值は北寄りの波浪場では概ね対応している と考えられるが，南寄りの波浪場では観測值と比較して 過小評価している，ただし，現地観測結果においても触 れたが，局所的な地形の影響が出ており，数值解析では その影響が十分に考慮できていない可能性がある. 


\section{4. おわりに}

本研究により，得られた結論をまとめると以下となる.

(1) リーフ周辺の現地観測の結果から，南側リーフに よる遮蔽の影響が確認された。 また，リーフフラット上 を伝播，通過する波が確認されたが，そのエネルギーは 小さく，リーフ周辺を回りこむ波浪が支配的であると考 えられる.

(2) リーフ周辺の波浪場は複雑ではあるものの, リー フ周辺を回りこむ波浪に着目すると，浅海域の波浪変形 モデルとしてエネルギー平衡方程式を用いて波浪評価し たところ，リーフ周辺を回りこむ波浪を含め概ね評価が 可能であった.

(3) WAM では評価できないリーフ地形による影響は, エネルギー平衡方程式による波高比を活用した簡易モデ ルを用いることにより，作業限界波高 $1.0 \mathrm{~m}$ 程度の波浪 予測に対する精度検証が実施でき，実務的な精度を有す る可能性が確認できた。

以上より，リーフ地形周辺の海上工事において，作業 可否を波高で判断する場合の基本的な知見を得た。 しか し，波向によっては遮蔽の影響が異なるリーフ地形にお いてはWAMの波向の精度が重要となる．また，多方向 性の波浪場においてはそれぞれの波向に応じた波高比を 用いるなどの工夫が必要であることや，簡易モデルを用 いる際にはWAMの周期の精度向上が今後の課題と考え られる. なお，今回の検討結果は特定のリーフを対象と した結果であるため, 他のリーフ地形も含め, 施工限界 波高付近の推算精度の検証は今後も必要であると考える.

謝辞 : 本研究を行うにあたり, 九州大学大学院の橋本典 明教授には，WAMモデルを用いた波浪予測について有 益な助言をいただきました．また，波浪予測結果の検証 に利用したNOWPHASデータは国立研究開発法人港湾 空港技術研究所海象情報研究チームのHPより入手させ ていただきました。ここに記して関係者に謝意を表しま
す.

\section{参考文献}

1）川口浩二，猪股勉，関克己，藤木峻：全国港湾海洋波 浪観測年報（NOWPHAS 2012），港湾空港技術研究所 資料，No.1282，2014，125p.

2) 江口一平, 岡田弘三, 中田玩志, 内田洋平, 窪田和彦, 宇都宮 好博 : 沿岸気象海象情報配信システムの高度 化, pp.61-66, 土木学会論文集 B3 (海洋開発), 2014.

3) 森屋陽，琴浦毅，関本恒浩：日本海における波浪推算モ デルを用いた海上・潜水作業可否の予測精度, 海洋開発論 文集，第 26 巻, pp.447-452, 2010.

4) 琴浦毅, 森屋陽一, 関本恒浩 : 波浪推算の計算領域が 海上作業可否の判定精度に及ぼす影響, 土木学会論 文集 B3 (海洋開発)，Vol.67，No.2，pp.I_880-I_885， 2011.

5）琴浦毅，森屋陽一，関本恒浩：瀬戸内海における波浪 推算モデルを用いた海上作業可否の判定精度，土木 学会論文集 B3 (海洋開発), Vol. 68, No. 2, pp.I_959-I_964, 2012.

6) 津嘉山正光，河野二夫，仲座栄三，大城真一，福田孝 晴 : リーフ上の波の変形に関する研究, pp.176-180, 海岸工学論文集, 第 42 巻, 1995.

7) 高山知司, 神山豊, 菊池治：リーフ上の波の変形に関 する研究，港湾技研資料，No.278，1977，32p.

8）平山克也, 川内清光, 宮里一郎, 田中和広 : 平面リ一 フ上の護岸越波量推定に関する実験的考察, pp.746-750, 土木学会論文集 B2 (海岸工学), 2013.

9) 平山克也, 春尾和人, 宮里一郎: ブシネスクモデルを 用いて算定したリーフ上護岸の設計諸元に関する考 察，港空研報告，第 48 巻，第 3 号，pp. 23-74， 2009.

10) 高山百合子, 伊藤一教, 織田幸伸, 片倉徳男 : 海洋工 事における濁り予測のための簡易流況計算手法に関 する研究, pp.1140-1145, 土木学会論文集 B3（海洋開 発), 2014.

11) 永井紀彦:全国港湾海洋波浪観測 30 力年統計 (NOWPHAS1970-1999), 港湾空港技術研究所資料, No.1035, 2002, 388p.

\section{EXAMINATION OF WAVE PREDICTION ACCURACY FOR MARINE WORKS AROUND THE REEF AREA}

\section{Tsuyoshi KOTOURA and Hiroyuki KATAYAMA}

In marine works, it is important to get wave prediction results for safety operation and work executable judgment. Recently, the advanced wave prediction method using the WAM model has been utilized generally in marine works. However, the accuracy of the wave prediction results is not clear in marine work conditions.

In this study, we observed field wave around reef area, and constructed of the wave prediction model composed the WAM model (offshore) and an energy balance equation (onshore). From the comparison with the model prediction results and the wave measurement results, we discussed the accuracy of the wave prediction results for marine works around the reef area. As a result, the wave prediction model can estimated precisely the wave height at the coastal wave gauge site, but sometimes differ between before and after the wave direction changes. 